\title{
7. The impact of the European Charters in times of crisis and their role in effectuating social justice ideals for European citizens
}

\section{Barbara Safradin and Sybe de Vries ${ }^{1}$}

\subsection{INTRODUCTION}

Justice is conceived as the normative basis upon which the European Union (EU) is founded. ${ }^{2}$ But events of the 21 st century such as the financial and migration crisis, and the terrorism threats have led the EU to put justice on a higher agenda (Douglas-Scott 2017). Particularly important in this respect have been the effectuation of fundamental (social) rights at EU level through the binding EU Charter of Fundamental Rights (CFR) attached to the Treaty of Lisbon (2009), and the proclamation of social justice and a highly competitive social market economy in Article 3(3) of the Treaty on the European Union (TEU). In addition, the Council of Europe (CoE) has long been a promoter of social rights with the CoE Revised Social Charter (R-ESC) constituting the key regional instrument for the protection of social rights of European citizens.

Nevertheless, it has been argued that the EU's handling of the Eurozone crisis has illustrated a lack of solidarity and disregard for justice claims at EU level (Douglas-Scott 2017). Especially Eurozone Member States with sovereign debt crises such as Greece, Portugal, Ireland, Cyprus and Romania were hit by this crisis, whereas of the non-Eurozone Member States, Hungary, the United Kingdom and Latvia were particularly affected (de Vries and Safradin 2018). These countries were subject to external conditionality regimes, which involved cuts in wages, pensions and welfare services. The austerity measures resulted in persistent violations of social rights and justice of their citizens, which have been challenged before national courts, the European Court of Justice (CJEU) and the European Committee of Social Rights (ECSR).

The main question that this chapter seeks to address is whether and if so, how fundamental social rights as laid down in the CFR and the R-ESC have been applied in Europe in times of crisis to effectuate social justice for 
European citizens. Moreover, it will assess which future challenges exist for European citizens in accessing social justice claims through the European Charters. These social rights relate to values of 'equal treatment and respect' and 'freedom', values upon which the Union is founded. As such, the capability of individuals to enjoy their social rights should be a central consideration of social justice (understood in the spirit of Nancy Fraser as participatory parity) in all EU Member States. However, the degree to which European states meet ideals of distributive, representative or recognitive justice varies widely (see Chapter 4 for a detailed discussion of Fraser's tri-partite framework of justice that informed the ETHOS project and this book). In fact, the austerity measures that were adopted in the economic crisis have resulted in the unfair distribution of resources, which fuels deprivation of social rights and inequality within and between societies (de Vries and Safradin 2018).

The chapter is organised as follows. The first section will draw particular attention to the notion of social justice in the European legal order. Hereafter, the limitations of the CFR in the social domain will be addressed, in particular when it comes to realising social justice in times of crisis. The third section illustrates the specifics of how several legal and natural persons attempted to invoke the CFR and R-ESC to challenge the austerity measures taken in the wake of the economic crisis, with a particular focus on the role of the CJEU and the ECSR in this matter. Lastly, some recommendations are given on how these instruments could be utilised in the future in order to better promote, respect and protect fundamental social rights of European citizens in crisis times. As such, this chapter allows us to illustrate what still remains to be done so that fundamental social rights become a reality for everyone in Europe, including the most vulnerable ones in society. The chapter largely draws upon the ETHOS research conducted by de Vries and Safradin (2018).

\subsection{PAVING THE WAY TOWARDS A SHARED CONCEPT OF JUSTICE IN THE EU?}

The 2009 Lisbon Treaty has for the first time explicitly referred to the notion of 'social justice', stipulating in Article 3 of the TEU that the Union 'shall promote social justice'. With this provision, the EU legislator has explicitly raised attention and importance to social rights in the hierarchy of EU values. Scholars such as Sionaidh Douglas-Scott have raised the question as to whether it is possible to secure 'social justice' in an EU which has for so long focused on a market-driven rationale. In fact, EU legislation has been beneficial in the field of equality law, in particular in the domain of equal treatment between men and women, and especially the right to equal pay for equal work for male and female workers. The CJEU gave this right as enshrined in Article 
157 of the Treaty on the Functioning of the European Union (TFEU) the status of a fundamental right in the Defrenne II case. ${ }^{3}$

But the justification for the adoption of a EU legal framework in this field was predominantly found in the need to prevent distortions of competition and to create a level playing field in the EU's internal market (de Vries and Safradin 2018). The EU's approach to equality thus seemed more market driven than fundamental rights' driven with a view to realise more equality amongst citizens. Douglas-Scott argues in this context that:

[I]t is difficult to see how the EU can promote itself as the sort of social market community urged, for example, by Habermas, when so many of its members would veto such a role for it (no doubt in many cases due to an absence of solidarity), and when the austerity measures taken in the wake of the Eurozone crisis undermine social justice. (Douglas-Scott 2017, p. 63)

Furthermore, adding a social dimension to the EU's internal market has not been easy since many of the EU Member States do not stand behind the idea of a common, harmonised, redistributive social policy as they are divided about whether a social welfare system should be more market driven or redistributionist (Douglas-Scott and Hatzis 2017). But it should be emphasised that social objectives have long been recognised as part of the EU's internal market, which was confirmed in the above-mentioned Defrenne II case wherein the Court held that what is now Article 157 TFEU 'forms part of the social objectives of the Community which is not merely an economic union, but is at the same time intended to ensure social progress and the constant improvement of the living and working conditions of their people'. In addition, in various documents of the European Commission and the Council, the importance of the social dimension of the internal market was recognised. However, as stated above, the creation of a more social Europe was originally not seen as an aim in itself. As a consequence, the EU's competences in the social policy field remained limited, which meant that EU measures, including those adopted in the wake of the crisis remained ad hoc and fragmented, and resulted in social injustice for European citizens. Douglas-Scott argues that this resultant injustice is indeed attributable to a so-called 'asymmetrical and unbalanced integration' (Douglas-Scott 2017, p. 63).

Despite the lack of legislative powers for the EU to protect EU citizens against social injustice, we should point at the (potential) impact of the CFR to counterweight austerity and to strengthen redistributive (for example, right to housing, social benefits), recognitive (for example, right to education) and representative (for example, right to collective action; representation in a trade union) justice. Yet some of the stringent austerity measures that have been adopted in the wake of the Eurozone crisis appear to be contradictory to the 
social fundamental rights as laid down in the European Charters as well as to the EU's desire to foster social justice within the meaning of Article 3 TEU (Douglas-Scott 2017).

Against this background, the EU and particularly the EU Member States created a perfect 'vacuum of irresponsibility' in which they can blame each other for most of the pitfalls. This suggests that Europe is characterised 'by justice at default. Justice values and norms remain holding principles in abstraction, less so in practice' (Knijn et al. 2019, p. 85; see also Chapter 13). Having said that, the focus of justice as a social and political concept entails a deeper understanding of justice, which also requires, as Douglas-Scott argues, 'nurturing freedom and the realisation of justice'. She thereby advocates for human rights as a 'powerful symbolic and actual force' for justice and a better departure for achieving justice in the EU (Douglas-Scott 2017, p. 59).

\subsection{THE CFR AND LIMITATIONS FOR SOCIAL RIGHTS PROTECTION}

Despite the fact that the CFR became legally binding with the Lisbon Treaty in 2009 and despite its potential for the protection of citizens' social rights, there are still important limitations that could restrict justice realisation for EU citizens, which will be highlighted below.

\subsubsection{Limited (Scope of) Application of the CFR in Respect of Social Rights}

Article 51(1) of the CFR stipulates that the rights of the Charter apply to the EU institutions and only to the Member States when they are implementing Union law. The CJEU played a pivotal role in broadening the scope of the CFR. For example, it further interpreted this right in its landmark judgment A kerberg Fransson, in which it argued that the rights as laid down in the CFR must be respected in all situations in which national legislation falls 'within the scope of EU law' and it thereby equated 'implementation' with 'scope of application' ${ }^{4}$ At the same time, it restricted the Charter's scope again in Siragusa, in which the CJEU held that this order did not trigger the application of Article 17 of the CFR since the national law at issue did not have any corresponding obligations under EU law (de Vries and Safradin 2018, p. 14). However, the Court's case law is not always clear on what this exactly entails. In the case of Dano, for instance, the Court was unwilling to apply the Charter despite the fact that Germany acted within the framework of EU legislation, which in other Court decisions sufficed to trigger the CFR. In this case, a Romanian national legally residing in Germany could not seek a remedy under the CFR 
as Member States are not competent to determine the conditions for granting social benefits (de Vries 2019).

Moreover, another limitation of the CFR in effectuating social justice is that Article 51(2) of the Charter stipulates that this instrument 'does not extend the field of application of Union law'. The CFR in itself cannot, for instance, constitute a legal basis for legislative action in the social policy field.

\subsubsection{Rights versus Principles Dichotomy: The CFR's Solidarity Rights Title}

Compared to the R-ESC, the CFR constitutes a broader catalogue of rights with the specific Solidarity Title IV covering various social and workers' rights. These rights include the right to fair working conditions, protection against unjustified dismissal, and access to health care, social and housing assistance. All EU Member States are bound to the social rights in this document, except for the United Kingdom and Poland who have secured Protocol No. 30. This Protocol provides that the Solidarity Chapter containing social rights cannot create justiciable rights different from the degree that such rights are already protected under national law.

Nevertheless, the CFR includes a complicated distinction between so-called 'rights' and 'principles' as laid down therein. This distinction is particularly relevant for social rights. More specifically, Article 52(5) of the CFR stipulates the following:

[t] he provisions of this Charter which contain principles may be implemented by legislative and executive acts taken by institutions, bodies, offices and agencies of the Union, and by acts of Member States when they are implementing Union law, in the exercise of their respective powers. They shall be judicially cognisable only in the interpretation of such acts and in the ruling on their legality.

In other words, this refers to the idea that rights, which contain so-called 'principles' within the context of Article 52(5) of the CFR cannot create directly enforceable rights for individuals that want to invoke them before courts (that is, representative justice). Even more so is the fact that this provision does not explicitly refer to which rights can be regarded as 'principles' and which provisions can be seen as so-called 'principles'. An example can be found in Article 34 of the Charter, which stipulates the following:

[t]he Union recognizes and respects the entitlement to social security benefits and social services providing protection in cases such as maternity, illness, industrial accidents, dependency or old age, and in the case of loss of employment, in accordance with the rules laid down by Union law and national laws and practices. 
The idea behind this distinction is that there exists a 'dichotomy between individual and fully enforceable rights on the one hand, and programmatic norms (principles) that require the intervention of the legislator or the executive ... on the other' (Peers and Prechal 2014, pp. 1505-6). However, although Article 52(5)'s aim was to clarify the judicial nature of rights and principles and to thereby reinforce legal certainty, it has been questioned whether this provision in fact does not lead to more confusion. Deciding which provision contains a right or principle is complex, and introducing a new category of principles - EU law already contains a range of various principles - is not really helpful. In such circumstances, it is important to assess whether EU law or policy exists in this field, since the principle shall then 'be judicially cognisable only in the interpretation of such acts in the ruling on their legality' (Article 52(5)). The CJEU could play an important role in explaining Article 52(5) and in interpreting the principles contained in the Charter. The Court had the opportunity to do so in the Association de Médiation Sociale (AMS) case, which concerned Article 27 of the CFR on workers' right to information and consultation within the undertaking. But the Court did not embroider on the distinction of rights and principles as laid down in Article 52(5) of the Charter. By contrast, the Advocate General addressed the content of Article 27 of the Charter and thereby held that in the Charter as well as in national constitutions, claims of the nature of social rights are typically designated as 'social rights' to indicate that no individual subjective rights can be derived from them, but they only function via the implementation or enforcement through the State. They can then be regarded as 'rights' in terms of their content and nature, but 'principles' in terms of their enforcement (de Vries and Safradin 2018). This led many to believe that (most of) the social rights in the Solidarity Title should be considered principles, until the Court's decisions in Bauer et al. and Max Planck, which will be discussed hereafter.

\subsubsection{The Question of Horizontal Direct Effect of the Charter Provisions in the Social Domain}

Another important point to make regarding the scope of the CFR is the issue of horizontal application of fundamental rights. To what extent do the rights contained in the Charter apply in horizontal relationships - that is, between private parties, and can they be invoked before a national court in a dispute between private parties (that is, horizontal direct effect)? Within the context of the Eurozone crisis, this question is of particular importance with respect to labour disputes between employers and employees, and the litigation process. An example of a CFR provision that is horizontally directly effective is Article 23 , which lays down the principle of equality between men and women 'in all 
areas'. However, not all provisions in the Charter enjoy horizontal effect (de Vries and Safradin 2018).

It is often the CJEU that decides which provisions of EU primary law, including the CFR, and of secondary EU law, can enjoy full horizontal direct effect. In the $A M S$ case for example, the CJEU argued that this provision does not have horizontal direct effect, meaning that it cannot be invoked in labour-related proceedings between private parties, because it does not have direct effect in the first place. It argued in particular that it is 'clear from the wording of Article 27 of the Charter that, for this article to be fully effective, it must be given more specific expression in European Union or national law'.5 But the CJEU did not explicitly exclude the possibility of Charter provisions having horizontal direct effect either.

In another earlier case, Kücükdeveci, the CJEU applied a different approach in assessing the possibility of horizontal direct effect of EU fundamental rights, building upon its prior judgment in Mangold. In Kücükdeveci the CJEU held that non-discrimination on the basis of age, as a general principle of EU law can enjoy horizontal direct effect, also in situations in which EU secondary legislation such as directives are incapable of having such an effect. In this case, the CJEU provided strong hints that Charter principles that embody the general principle of non-discrimination on age can have horizontal direct effect. The Court argued that, unlike Article 27 of the Charter in $A M S$, the principle of non-discrimination on grounds of age laid down in the Charter under Article 21 'is sufficient in itself to confer on individuals an individual right which they may invoke as such' ${ }^{6}$ This finding thereby differentiates the Kücükdeveci judgment from the AMS case (de Vries and Safradin 2018).

In the 2018 judgment of Bauer et al., concerning the right to paid annual leave in case of death as laid down in Article 31(2) of the Charter, the CJEU took a new position on horizontal direct effect of the CFR in the field of social rights. ${ }^{7}$ In this judgment the Court did not only rule that the rights in the Charter can have horizontal direct effect (that is, that they can be applied vis-à-vis other individuals) but also that this may go true for fundamental social rights laid down in the Solidarity Title IV, provided that these rights are directly effective in the first place. This judgment thus illustrates that the CJEU has taken a first and important step in acknowledging that fundamental social rights, in particular the right to paid annual leave, enjoy (horizontal) direct effect. Until now, this has only been the case in the field of non-discrimination and internal market cases. With Bauer, the CJEU has expanded this rationale to social rights, in addition to non-discrimination rights and as such, as Sarmiento argues, has opened up 'a new playing-field in the enforcement of social rights in Europe' (Sarmiento 2018). By this and by emphasising that Article 31(2) constitutes an essential principle of EU social law Bauer et al. may contribute to the attainment of a social market economy as laid down in Article 3(3) of 
the TEU, thereby reinforcing the protection of social rights for EU citizens (de Vries and Safradin 2018). The Court in Bauer et al. also explicitly refers to Article 51(1) of the Charter and the addressees mentioned therein. It thereby explicitly rejects the argument that the Charter would never apply to private parties as Article 51 only mentions EU institutions and its Member States. By pondering on the personal scope of application the Court thus affirms horizontality of the Charter provisions in principle (de Vries 2019).

\subsection{THE (IN)APPLICABILITY OF EU LAW DURING THE FINANCIAL CRISIS AND THE CJEU'S ROLE}

As argued above, social rights as laid down in the CFR can only be applied when the situation falls within 'the scope of Union law' as laid down in Article 51(1) of the Charter and further elaborated in the Akerberg Fransson judgment. The CFR does not operate in a vacuum, which means that there must be another 'accompanying' or 'supportive' provision of primary or secondary EU law, which triggers the application of the CFR. That the threshold for application may be high particularly follows from a stream of judgments by the CJEU on austerity measures adopted during the 2008 financial crisis. This case law is exemplary of the Court's reluctance to rely on the CFR where the compatibility of national austerity measures with Union law is concerned, thereby disregarding justice claims of EU citizens (de Vries and Safradin 2018). In a majority of these cases the Court held that the Member States were not 'implementing Union law' within the meaning of Article 51(1) of the Charter and that it therefore lacked jurisdiction. On this point, Peers argues that the Court's unwillingness to apply the CFR was not justified, even when adopting a narrow definition of the application of EU law, since Council measures had been implemented in these cases on the basis of Article 122 and 143 TFEU that expressly required the reduction of costs to be implemented (Peers 2014).

There are a number of reasons which explain the CJEU's hesitance to apply the CFR in austerity cases. First of all, some financial assistance programmes which have been implemented on the basis of the European Stability Mechanism (EStM), the European Financial Stability Facility (EFSF) and bilateral loan agreements executed by Greece did not fall within 'the scope of Union law' for the purposes of Article 51 of the Charter (de Vries and Safradin 2018). One landmark case that illustrates this is Pringle. ${ }^{8}$ This judgment concerned the legality of the EStM Treaty, which is a treaty under public international law concluded by the Members of the Eurozone, with the aim of creating a permanent crisis mechanism to safeguard the stability of the Eurozone area. Despite the fact that the application of the CFR was not the main point to be addressed in the Pringle case, the CJEU did stipulate that Article 122(2) 
TFEU, which provides the Union the competence to grant ad hoc financial assistance to Member States that are threatened with severe difficulties caused by natural disasters or exceptional occurrences beyond its control, did not provide for an appropriate legal basis for the establishment of the EStM. In this context, the Court argued that the adoption of the EStM does not infringe the principle of effective judicial protection as covered under Article 47 of the Charter and as such the situation does not fall 'within the scope of' EU law within the meaning of Article 51. In a similar way, the European Commission stated that when giving to these memoranda, Greece did not 'implement' EU law under the terms of Article 51 of the Charter and therefore the CFR did not apply (Koukiadiaki 2019).

A second reason that explains the cautious approach of the CJEU concerns the (in)ability of a link between a relevant EU law source and a Member State action (Koukiadaki 2019). The ETHOS case study of Portugal is relevant to mention in this context. The Troika, composed of the International Monetary Fund (IMF), the European Central Bank (ECB) and the European Commission, negotiated the international bailout for Portugal in the period 2011 and 2014. Part of these negotiations consisted of the adjustment programmes, including the conditions on financial support, conclusion of loan agreements, and monitoring the implementation thereof (Douglas-Scott and Hatzis 2017; see also Chapter 11). Since 2010, Portugal has been subject to withdrawal of policies aimed at combating poverty and social precariousness, justified by the necessity to control the public deficit. The austerity measures of the Portuguese state predominantly consisted of freezing almost all social and pension benefits, which led to a significant lowering of social rights protection for Portuguese citizens (de Vries and Safradin 2018). The international bailout by the Troika consisted of a Memorandum of Understanding (MoU) that was signed by the European Commission on behalf of the EU and the Member States. The most important elements of the MoU were incorporated into Council Decision 2011/344/EU (de Vries and Safradin 2018). During this period, litigants ranging from trade unions, companies and natural persons challenged the national budgetary measures that infringed their social justice realisation (de Vries and Safradin 2018). In numerous cases, the CJEU declined to answer preliminary references submitted by Portuguese lower courts that questioned the compatibility with the CFR with national austerity measures that implemented the MoU (Douglas-Scott and Hatzis 2017).

In the case Fidelidade Mundial and Via Directa, a Portuguese trade union was seeking a restitution of the collectively agreed holiday and Christmas allowances that were suspended by the State Budget Act for 2012 in State-owned insurance enterprises (de Vries and Safradin 2018). The referring Portuguese labour courts from Lisbon and Oporto sent preliminary references to the CJEU, questioning whether the latter measures complied with the fun- 
damental rights as laid down in the CFR, in particular the right to equality and non-discrimination (Article 20 and 21), and the right to fair and just working conditions (Article 31(1)). In October 2014, the CJEU declared the preliminary reference by the Portuguese courts inadmissible, for lack of jurisdiction to review Portuguese law vis-à-vis the CFR. It argued in particular that the austerity measures that were taken by the Portuguese government and included in the State Budget for 2012 did not trigger EU law and therefore fell outside its jurisdiction. The CJEU referred to an earlier decision in which it had already dismissed on the same grounds a preliminary reference by a Portuguese court challenging a similar austerity measure included in the State Budget Act for 2011. ${ }^{9}$

In the Sindicato dos Bancários do Norte case, the CJEU held that in line with its established case law, the CFR and its requirements are only binding upon Member States when 'they are implementing EU law' as stipulated in Article 51 of the Charter. It continued that under Article 6(1) TFEU, the Charter is binding and has the same value as primary EU law, but it does not create new EU competences nor modify existing ones. ${ }^{10}$ Again, the CJEU declared itself inadmissible to rule on the issue at hand since the contested national provision at issue was not implementing Union law. In the Fidelidade Mundial case, the CJEU argued that the facts at hand had the same nature as in the Sindicato dos Bancários do Norte case and as such the referring questions were analogous to the latter case. Therefore, the Court concluded that neither the 2011 nor 2012 Budget Acts were implementing Union law in the sense of Article 51(1) (Barnard 2013).

A further obstacle that adds to the CJEU's unwillingness to apply the CFR in the crisis context is that national austerity measures could also conflict with other international instruments and organisations that protect social rights, such as the R-ESC, International Labour Organization (ILO), United Nations (UN) and IMF (de Vries and Safradin 2018). These international systems have their own reporting mechanisms and remedies available and one could argue that the availability of these mechanisms provides litigants with alternative remedies in cases in which the CFR does not apply (de Vries and Safradin 2018). At the same time, the careful approach of the CJEU in the austerity context is contrary to its established line of cases regarding, for example, economic rights and civil rights, in which it has often taken a generous approach in reconstructing the applicability of EU law, and refusing the cases at hand only when the situation has no link at all with Union law.

In any case, in the above stream of austerity cases, exposing the limitation of Article 51(1), the CJEU clearly restricts litigants from effectuating social justice claims and the rights that they enjoy under Union law. It is therefore safe to conclude that the application of the CFR has not (yet) resulted in an 
effective mechanism for EU citizens to challenge the infringement of social labour rights in the context of the economic crisis (Koukiadaki 2019).

\subsection{THE IMPACT OF THE ECSR ON SOCIAL JUSTICE IN TIMES OF CRISIS}

In addition to the CJEU, the ECSR has been, and still is to this date, an important body that monitors the compliance of the R-ESC. It has, unlike the CJEU, been very active in responding to social rights violations in times of crisis. This section will take a closer look at the impact and role of the ECSR in the austerity context.

The R-ESC is a counterpart to the European Convention on Human Rights (ECHR), the latter embodying civil and political rights. It guarantees a broad range of everyday human rights related to employment, housing, health, education, social protection and welfare and considers these rights to be basic and intrinsic rights for everyone in Europe. Important to mention is that the R-ESC is a CoE instrument which applies also to non-EU states, such as Turkey, whereas all EU Member States are parties to the CFR. Within the context of the current project, Portugal and the Netherlands are the only State parties that have implemented (almost) all provisions of the revised R-ESC in their national legal framework (de Vries and Safradin 2018). Despite its increased visibility and relevance to policy areas impacted by EU law, the R-ESC has in most cases been overlooked under EU law, specifically regarding the protection of fundamental social rights in the EU legal order (de Vries and Safradin 2018). Despite this, the ECSR has had an active role in holding States accountable for violations of social rights during the economic crisis. It has two procedures in place to ensure that State Parties comply with their commitments under the Charter: (1) publishing national reports with recommendations and (2) the collective complaints procedure, allowing trade unions and non-governmental organisations (NGOs) with consultative status to present complaints to the ECSR. A Protocol opened for signature in 1995, which came into force in 1998, allows national and international trade union organisations, employers' organisations and NGOs to submit their complaints on violations of the R-ESC. Among the countries included in the analysis, Hungary, the United Kingdom, Austria and Turkey have not ratified this Protocol, while Portugal and the Netherlands did (de Vries and Safradin 2018).

Unlike the CFR, the R-ESC is not subject to limitations regarding its scope and thereby does not restrict litigants from effectuating social justice claims and the rights laid down therein, albeit it must concern a collective complaint procedure in which trade unions and NGOs with consultative status can present complaints to the ECSR. Individual situations may not be submitted here. The 
R-ESC has been essential in the protection of social labour rights of various vulnerable groups in Europe in times of crisis (de Vries and Safradin 2018).

The binding conclusions of the ECSR are of significant importance for the adequate protection of social rights in times of crisis. In its conclusions of 2009, the ECSR stipulated that:

the economic crisis should not have as a consequence the reduction of the protection of the rights recognised by the [European Social] Charter. Hence, the governments are bound to take all necessary steps to ensure that the rights of the Charter are effectively guaranteed at a period of time when beneficiaries need the protection most. ${ }^{11}$

The ECSR has been particularly active against Greece, Portugal and Spain in responding to social rights violations as a result of austerity measures taken during the crisis. ${ }^{12}$ It stipulated in the case on the PanHellenic Federation of pensioners $v$. Greece that 'states parties ... should - both when preparing the text in question and when implementing it into national law - take full account of the commitments they have taken upon ratifying the European Social Charter'. ${ }^{13}$ At the same time, the ECSR has argued that social rights, such as the right to housing, could not be interpreted as an obligation of results towards States, showing the cautiousness of the ECSR towards positive redistributive obligations in the social domain (Granger 2019).

The ECSR has condemned various State parties in recent years for justice violations, that is, for not providing free health care services to undocumented immigrants, but also other violations of the right of refugees' establishment of working conditions below the minimum acquired and prohibiting the right to strike. In the case of Greece, the ESCR has argued that the legislative reforms that were taken in the wake of the Troika measures did not comply with the R-ESC and should therefore be annulled. This concerned in particular measures regarding tackling of youth unemployment, where Greece limited the social security coverage for youngsters (Article 12(3)), such as a salary below the poverty level, which violated their right to a remuneration that guarantees a decent standard of living and their right to enjoy social rights without discrimination. ${ }^{14}$

In Turkey, trade unions used the ECSR complaint procedure to criticise workers' right to organise, especially during the instalment of the state of emergency by the Turkish government. In 2017, Turkey prohibited five strikes under the state of emergency, thereby arbitrarily curtailing the human rights and representative justice claims of their citizens. Despite the fact that Turkey lifted the state of emergency, to date the country still does not effectively implement the provisions of the R-ESC, specifically when it comes to labour rights and anti-discrimination on the labour market. Dismissed workers do 
not enjoy a right to appeal and are blacklisted from other jobs (de Vries and Safradin 2018, p. 30).

Many of the social rights as laid down in the CFR are based on or correspond to the provisions of the R-ESC. At the moment, the CFR requires the case law of the ECtHR to be taken into account, while no analogous obligation exists to refer to the ECSR conclusions or case law. Despite this, judgments and conclusions of the ECSR are important legal sources that give meaning to the provisions laid down in the R-ESC (Peers 2014). The R-ESC moreover contains certain rights that are more detailed than the ECHR, such as the right to education (that is, justice as recognition), albeit it has a more limited enforcement mechanism than the ECHR and the CFR, consisting of merely monitoring and a collective complaint procedure. Hepple (2001) argues that the interpretations as given by the ECSR should at least be equally given the same value as the ECtHR in the EU legal order. The fact that the legal status of the R-ESC has not been explicitly coordinated with the ECHR in the EU legal order, and that the CJEU only refers to the R-ESC in passing, poses a serious limitation to fostering social justice in the EU (de Vries and Safradin 2018).

\subsection{FUTURE CHALLENGES AND RECOMMENDATIONS FOR SOCIAL JUSTICE REALISATION IN EUROPE}

The following policy recommendations have been identified to allow the EU legislator to move towards a more comprehensive European Social Welfare model, in which all citizens and their justice ideals in Europe, regardless of their status, are being protected:

1. Elevation of so-called social principles in the CFR - which do not constitute self-standing rights - into enforceable rights which have the same status as civil and political rights.

2. Despite the fact that the EU has limited competences in the social domain, the EU legislator should consider to launch the process of EU accession to the R-ESC (Wixforth and Hochscheidt 2019). The legal basis for such an accession could perhaps be found in Article 216(1) TFEU, considering the number of areas covered by the R-ESC in which the EU has attributed powers to the Member States. The accession is also in line with the action plan of the newest European Commission President Ursula von der Leyen who wants to foster a Social Europe: 'in our Social Market Economy we must reconcile the market with the social. Therefore I will refocus our European Semester to make sure we stay on track with our Sustainable Development Goals.' ${ }^{15}$ The EU's accession to the R-ESC could moreover reinforce the implementation by Member States of the European Pillar of 
Social Rights as adopted in November 2017, which is a non-binding document that aims to deliver new and more effective social rights for citizens, building upon (a) equal opportunities and access to the labour market; (b) fair working conditions; (c) social protection and inclusion. At the moment, it is not clear who is in charge of the enforcement of these rights at national level. If certain actors such as trade unions and civil society organisations would mobilise themselves and put weight on this document at the national and EU level (that is, bodies that demand responsibility and hold EU and national governmental structures accountable under the R-ESC), this could provide for a more binding force of this instrument. Unfortunately, the mandate and interest of these actors in reinforcing higher social standards at the European level differs in each Member State.

3. In order for the CJEU to play a more visible role in social justice protection and to 'socialise' or make more inclusive its case law, Wixforth and Hochscheidt (2019) argue that it would be desirable to introduce European minimum standards in the form of directives in more socially related legal fields. At the same time, implementation thereof highly depends on the political will of Member States in this area. The question then is how we can guarantee that any EU-wide harmonisation of social policies does not result in agreement on the lowest common social standards. In the view of trade unions, implementation of a 'social progress protocol' would then be necessary (Wixforth and Hochscheidt 2019).

4. More awareness should be created on the use of the CFR in the judicial domain, particularly when it comes to the application of this instrument by national judges. The scope of EU law is the broadest at national level and as such, the impact of the CFR is highly relevant for national authorities, national legislators and courts. However, according to Eurobarometer surveys and research of the Fundamental Rights Agency of 2018, there is insufficient awareness and implementation of the CFR in the 28 Member States.

In a politically divided area such as social policy and employment, where decisions largely fall within the scope of Member States' competences, EU action to implement these policy recommendations, and specifically EU accession to the R-ESC, can only be limited. Furthermore, there must be a political will on the part of the Member States to realise social justice. At the same time, CJEU case law shows that in matters that are subject to EU regulation, such as non-discrimination, particularly on the enforcement of the non-discrimination principle concerning equal pay for men and women (that is, justice as redistribution), the CJEU has proved to be a real defender of the European acquis (Wixforth and Hochscheidt 2019). 
However, where social policy fields have not been subject to harmonisation at EU level - including the rights of association and withdrawal of labour, wages, and the amounts of social benefits (including minima) - the CJEU has fewer possibilities to act. Against this background, an even more fundamental question for today's social justice experience would be the adequacy of the division of powers, particularly whether it is desirable and beneficial to extend Europe's competences in the social domain, including the adoption of minimum EU standards on social policy regulation (de Vries and Safradin 2018).

\subsection{CONCLUSION}

The recognition of fundamental rights as general principles of EU law by the CJEU goes back to the late 1960s, with Internationale Handelsgesellschaft forming the first landmark case. Many years later, EU law expanded citizens' protection of fundamental social rights, in particular through the legally binding CFR (2009) and the adoption of the EU's Social Policy Agenda. This chapter has illustrated that the CFR is becoming increasingly important and is the first EU-wide instrument that includes both civil and political rights on the one hand and social rights on the other, thereby covering all layers of the ETHOS' justice taxonomy (that is, representation, recognition and redistribution) in one document. Despite this, the potential of social rights contained in the CFR is limited due to the limited scope of application of the Charter, their characterisation as principles rather than self-standing rights and the consequential unclarity as regards their horizontal direct effect, sometimes leaving individuals in private disputes without a remedy. Moreover, the EU's handling of the Eurozone crisis has illustrated a lack of solidarity and disregard for justice claims at EU level. The CJEU has only rarely dealt with fundamental social rights in the austerity context. The fact that the CFR is only applicable when national measures 'fall within the scope of Union law' can be seen as an inevitable restriction to the effective enforcement of social justice claims for EU citizens (de Vries and Safradin 2018).

Despite the fact that the CFR is largely inspired by the provisions of the R-ESC, the latter instrument has to a large extent been disregarded in the more recent developments concerning the protection of fundamental social rights in the EU legal order. Nonetheless, the role of the ECSR has been more active than the CJEU in the austerity context. The latter institution has played a pivotal role in the realisation of justice claims for European citizens at times when they needed it the most.

It is especially in moments of crisis that fundamental rights could remedy justice errors by providing a check against national austerity measures, which are inadequate and/or disproportionate (de Vries and Safradin 2018). The 
CJEU's role in this matter will be crucial to guide national courts in referring to the CFR and the R-ESC, particularly in areas in which social rights need to be balanced with economic freedoms. Nevertheless, the CJEU has limited the scope of its role in the financial crisis context, as was illustrated through Pringle and other subsequent rulings in which it disregarded the application of the CFR. This being said, in the latest Bauer ruling the Court expanded the force of social rights protection in private disputes and shows its willingness to place the burden of justice realisation on private parties as well. One of the examples that has already lifted social rights protection to a higher level in the EU is the adoption of the European Pillar of Social Rights of 2017, a development that should be applauded. As Douglas-Scott rightly points out, 'human rights are crucial and should play a vital role in European integration. Now is the time for the EU to move beyond ambivalence and to state clearly that it believes in human rights as the best route to justice' (Douglas-Scott 2017, p. 78).

\section{NOTES}

1. We would especially like to thank (former) student assistant Simona de Heer, who provided valuable insights and research assistance for this chapter.

2. Europe is here defined as the 'European social legacy', conceived as a mix of market economy, social regulations and a culture of human rights in the ETHOS selected Member States and Turkey.

3. Defrenne $v$ Sabena ECR 455 [1976].

4. See Akkerberg Fransson EU:C:2013:105, para. 21.

5. Association de Médiation Sociale (AMS) ECLI:EU:C:2014:2, para. 45.

6. Ibid., para. 47.

7. Stadt Wuppertal v Maria Elisabeth Bauer and Volker Willmeroth v Martina Broßonn EU:C:2018:871.

8. Thomas Pringle v Government of Ireland and Others EU:C:2012:756.

9. Sindicato dos Bancários do Norte EU:C:2013:149, para. 7.

10. Ibid., paras. 10-14.

11. ECSR, Conclusions 2009, Vol. I, para. 17.

12. Ibid.

13. ECSR, Complaint no. 79/2012, para. 47.

14. Ibid.

15. European Commission, Opening Statement in the European Parliament Plenary Session by Ursula von der Leyen, accessed 9 January 2020 at https://ec.europa.eu/ commission/presscorner/detail/it/speech_19_4230.

\section{REFERENCES}

Barnard, Catherine (2013), 'The Charter, the Court - and the crisis', University of Cambridge Faculty of Law Legal Studies Research Paper 8 (18), 1-16.

Douglas-Scott, Sionaidh (2017), 'Human rights as a basis for justice in the European Union', Transnational Legal Theory 8 (1), 59-78. 
Douglas-Scott, Sionaidh and Nicholas Hatzis (2017), 'EU law and social rights', in Sionaidh Douglas-Scott and Nicholas Hatzis (eds), Research Handbook on EU Law and Human Rights, Cheltenham, UK and Northampton, MA, USA: Edward Elgar Publishing, pp. 492-515.

Granger, Marie-Pierre (2019), 'Coming "home": the right to housing, between redistributive and recognitive justice', ETHOS report D3.5, accessed 1 February 2020 at https://ethos-europe.eu/.

Hepple, Bob (2001), 'The EU Charter of Fundamental Rights', Industrial Law Journal 30 (2), 225-31.

Knijn, Trudie, Jelena Belic and Miklós Zala (2019), 'Synthetizing ETHOS papers on the interplay and tensions between justice claims, mechanisms that impede justice and fault lines of justice', ETHOS report D7.3, accessed 14 February 2020 at https:// ethos-europe.eu/.

Koukiadaki, Aristea (2019), 'Application (Article 51) and Limitations (Article 52(1))', in Filip Dorssemont, Klaus Lörcher, Stefan Clauwaert and Mélanie Schmitt (eds), The Charter of Fundamental Rights of the European Union and the Employment Relation, Oxford: Hart Publishing, pp. 101-34.

Peers, Steve (2014), 'When does the EU Charter of Rights apply to private parties', EULawAnalysis.blogspot.com, accessed 15 January 2020 at http://eulawanalysis .blogspot.com/2014/01/when-does-eu-charter-of-rights-apply-to.html.

Peers, Steve and Sacha Prechal (2014), 'Article 52: scope and interpretation of rights and principles', in Steve Peers, Tamara Hervey, Jeff Kenner and Angela Ward (eds), The EU Charter of Fundamental Rights: A Commentary, Oxford: Hart Publishing, pp. 1455-1522.

Sarmiento, Daniel (2018), 'Sharpening the teeth of EU social fundamental rights', Despite our Differences blog, 8 November, accessed 16 November 2019 at https:// despiteourdifferencesblog.wordpress.com/2018/11/08/sharpening-the-teeth-of-eu -social-fundamental-rights-a-comment-on-bauer/.

Vries, Sybe de (2019), 'The Bauer et al. and Max Planck judgments and EU citizens' fundamental rights: an outlook for harmony', European Equality Law Review 2019 (1), 16-30.

Vries, Sybe de and Barbara Safradin (2018), 'The impact of the Social and EU Charters in times of crisis', ETHOS report D6.3, accessed 12 February 2020 at https://ethos -europe.eu/.

Wixforth, Susanne and Lukas Hochscheidt (2019), 'How the European Court of Justice could become the guardian of social rights', Social Europe blog, 4 November, accessed 16 December 2019 at https://www.socialeurope.eu/how-the-european -court-of-justice-could-become-the-guardian-of-social-rights. 